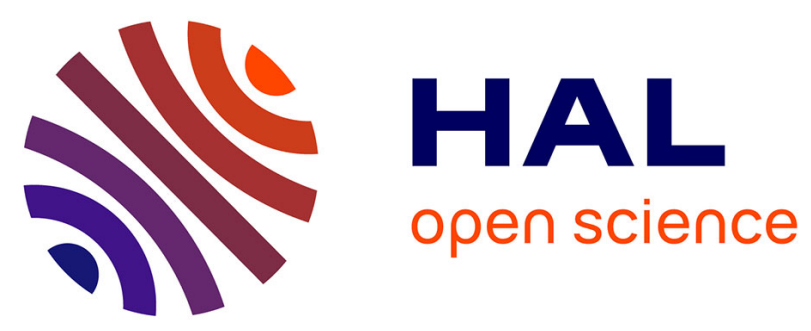

\title{
Tour de France, Giro, Vuelta, and classic European races show a unique progression of road cycling speed in the last 20 years
}

Nour El Helou, Geoffroy C.B. Berthelot, Valérie Thibault, Muriel Tafflet, Hala Nassif, Frederic Campion, Olivier Hermine, Jean-François Toussaint

\section{To cite this version:}

Nour El Helou, Geoffroy C.B. Berthelot, Valérie Thibault, Muriel Tafflet, Hala Nassif, et al.. Tour de France, Giro, Vuelta, and classic European races show a unique progression of road cycling speed in the last 20 years. Journal of Sports Sciences, 2010, 28 (7), pp.789-796. hal-01753726

\section{HAL Id: hal-01753726 \\ https://hal-insep.archives-ouvertes.fr/hal-01753726}

Submitted on 29 Mar 2018

HAL is a multi-disciplinary open access archive for the deposit and dissemination of scientific research documents, whether they are published or not. The documents may come from teaching and research institutions in France or abroad, or from public or private research centers.
L'archive ouverte pluridisciplinaire HAL, est destinée au dépôt et à la diffusion de documents scientifiques de niveau recherche, publiés ou non, émanant des établissements d'enseignement et de recherche français ou étrangers, des laboratoires publics ou privés. 


\title{
Tour de France, Giro, Vuelta, and classic European races show a unique progression of road cycling speed in the last 20 years
}

\author{
Nour EL Helou ${ }^{1,2}$, Geoffroy Berthelot ${ }^{1}$, Valérie Thibault ${ }^{1}$, Muriel Tafflet ${ }^{3}$, Hala Nassif ${ }^{1,2}$, Frédéric
} Campion ${ }^{1}$, Olivier Hermine ${ }^{4}$, \& Jean-François Toussaint ${ }^{2,5}$

${ }^{1}$ Institut de Recherche Biomédicale et d'Epidémiologie du Sport (IRMES), Paris,

${ }^{2}$ Université Paris Descartes, Paris,

${ }^{3}$ INSERM U909, Paris,

${ }^{4}$ Department of Haematology, Hôpital Necker, Paris, and

${ }^{5}$ CIMS, Hotel-Dieu, Paris, France

(article publié dans Journal of sports sciences, 2010, vol. 28, $n^{\circ} 7$, pp. 789-796)

\begin{abstract}
Road cycling ranks among the most intense endurance exercises. Previous studies and mathematical models describing road cycling have not analysed performances per se. We describe the evolution of road cycling performance over the past 116 years. We studied the top ten cyclists' mean speeds in eight famous classic races and three European Grand Tours, using a previously published multiexponential model that highlights the different progression periods of an event during the century. In addition, we measured an indicator of difficulty for the Tour de France by calculating the climbing index (i.e. the total altitude climbed over total distance). The eleven races' mean speed increased progressively from $23.13 \mathrm{~km} \cdot \mathrm{h}^{-1}$ in 1892 to $41.19+2.03 \mathrm{~km} \cdot \mathrm{h}^{-1}$ in 2008 . Road cycling development, like other quantifiable disciplines, fits a piecewise progression pattern that follows three periods: before, between, and after the two World Wars. However, a fourth period begins after 1993, providing a speed progression of $6.38 \%$ from the third one. The Tour de France's climbing index also provided insight into a recent paradoxical relationship with speeds: when the climbing index increased, the winner's speed also increased. Our results show a major improvement $(6.38 \%)$ in road cycling performance in the last 20 years and question the role of extra-physiological parameters in this recent progression. Keywords: Road cycling, technology, erythropoietin, speed records, physiological limits.
\end{abstract}

\section{Introduction}

Road cycling competitions are among the most intense of endurance exercises and take place in constantly changing conditions. Parameters influencing road cycling performance are numerous and include external and internal factors. External factors include climatic and environmental parameters, which are not controllable (Jeukendrup, Craig, \& Hawley, 2000; Jeukendrup \& Martin, 2001), development of technology and aerodynamic equipment (Faria, Parker, \& Faria, 2005), conditions specific to the race (course profiles and difficulty; Lucia, Hoyos, \& Chicharro, 2001; Padilla, Mujika, Orbananos \& Angulo, 2000), and advances in sport science (medicine, nutrition, and pharmacology). Internal factors include the rider's profile expressed as physiology, genetics, and anthropometry (Faria et al., 2005; Jeukendrup et al., 2000; Jeukendrup \& Martin, 2001; Lucia et al., 2001; Padilla et al., 2000). Other factors are improvements in training techniques and facilities, strategies and tactics designed for the race to reduce drag (air resistance) and save energy for the more demanding efforts of "escapes" from the bunch, climbs or sprints (Faria et al., 2005). The UCI (Union Cycliste Internationale), race organizers, and the cycling federations do not provide official road cycling world records, but rather measure riders' arrival times and mean speeds for each race; performance can thus be quantified as the riders' mean speed $(\mathrm{km} \bullet \mathrm{h}-1)$. Most previous studies and mathematical models on road cycling speed have not analysed race performance expressed as mean speeds, assuming that they 
might not be comparable from year to year due to changing conditions. Rather, they analysed performance expressed as maximal power output (Basset, Kyle, Passfield, Broker, \& Burke, 1999; Gonzalez- Haro, Galilea Ballarini, Soria, Drobnic, \& Escanero, 2007; Olds, Norton, \& Craig 1993; Olds et al., 1995).

Our aim is to describe the evolution of road cycling performance expressed as mean speeds, based on a previously developed model (Berthelot et al., 2008), based on the hypothesis that the progression pattern of road cycling is similar to that of other sports.

\section{Methods}

The mean speeds of top-ten riders and speed records were measured in 11 European classic races and Grand Tours, and compared with other quantifiable sport disciplines.

\section{Data collection}

Data collected for the 11 events included each race's total distance D $(\mathrm{km})$ and total times $\mathrm{T}(\mathrm{h})$ for the top ten riders each year from 1892 to 2008. A total of 8540 performances, including those of 854 winners, were obtained from Association Me'moire du Cyclisme (http://www.memoire-ducyclisme.net/), La Gazetta Dello Sport (http://www.gazzetta.it), Web Oficial de la Vuelta a España, and Tour de France official websites. Performance expressed as mean cycling speed $\left(\mathrm{km} \bullet \mathrm{h}^{-1}\right)$ was calculated as follows:

$$
\text { mean cycling speed }=\mathrm{D} / \mathrm{T}
$$

We studied three categories of races:

- four single-day races (Milan-San Remo first raced in 1907, Paris-Roubaix 1896, Flèche Wallonne 1936, and Liège-Bastogne-Liège 1892) with distances ranging from 200 to 290 $\mathrm{km}$;

- four stage races (Paris-Nice first raced in 1933, Dauphiné Libéré 1947, Quatre Jours de Dunkerque 1955, and Midi Libre 1949) with distances of $500 \mathrm{~km}$ (first editions) to $2100 \mathrm{~km}$ over 4-6 days of competition; and

- the three Grand Tours (Tour de France 1903, Giro d'Italia 1909, and Vuelta a España 1935) with distance ranging from 2250 to $5750 \mathrm{~km}$, usually over 3 weeks.

Winners' and top-ten riders' yearly mean cycling speeds were calculated for each race and race category.

\section{Descriptive race analysis}

Tour de France profiles were integrated from 1960 (no data available before 1960) to 2008 as the total altitude climbed $(\mathrm{m})$, calculated by the addition of all ascended mountain passes or summit altitudes (all categories), obtained from the sources cited above, and cross-checked with geographical sources (IGN Institut Géographique National). The climbing index (CI, \%o) was consequently calculated by dividing the total climbed altitude $(\mathrm{A}, \mathrm{m})$ by the total distance $(\mathrm{D}, \mathrm{km})$ :

$$
\mathrm{CI}=\mathrm{A} / \mathrm{D}
$$

\section{Model description}

Each series of yearly performances for each race was fitted by a previously developed piecewise exponential model (Berthelot et al., 2008):

$$
y_{j}(t)=\Delta \cdot \exp ^{\left(-a_{j} \cdot t^{\prime}\right)}+b_{j}
$$


where $y$ is the studied performance at year $t$ and $j$ is the studied period (a cycling race). $\Delta$ is the trend of performance evolution, $\Delta=\mathrm{p}_{\mathrm{i}, \mathrm{j}}-\mathrm{p}_{\mathrm{f}, \mathrm{j}}\left(\mathrm{p}_{\mathrm{i}, \mathrm{j}}\right.$ and $\mathrm{p}_{\mathrm{f}, \mathrm{j}}$ are the initial and final performance values respectively). In road cycling, $\Delta$ values are negative since $p_{i, j}$ is less than $\mathrm{p}_{\mathrm{f}, \mathrm{j}} . t$ ' is as previously defined by Berthelot et al. (2008):

$$
t_{j}^{\prime}=\frac{t_{j}-t_{i j}}{t_{f, j}-t_{i j}}
$$

where $t^{\prime}$ is the performance year after linear transformation of $t ; \mathrm{t}_{\mathrm{i}, \mathrm{j}}$ and $\mathrm{t}_{\mathrm{f}, \mathrm{j}}$ are the years of initial and final performance values in the current period $\mathrm{j}$, respectively. This uniformization of $\mathrm{t}$ in the $[0,1]$ interval ensures the objective function (see Berthelot et al., 2008, model function definition) to be well defined for all values of $t$. The "initial" and "final" performances of a period are the first and last performances $(y)$ included in the studied period $j . a_{j}$ is the positive curvature factor and $b_{j}$ is the asymptotic limit.

Coefficients $\mathrm{a}$ and $\mathrm{b}$ were obtained through a nonlinear least-squares regression, and estimated predictions (period years and number, asymptotic speed values) were calculated for the last period of each event with a credibility interval using a Monte Carlo simulation method. Previously estimated coefficients from the model equation (Berthelot et al., 2008) were used to draw 10,000 new coefficients in a bidimensional normal distribution. The new coefficients were then used in the model's equation to produce 10,000 performance values. We used the 2.5 th percentile, median, and 97.5th percentile of these 10,000 draws to produce the prediction errors for the estimated year at $99.95 \%$ and the estimated asymptotic values. The credibility interval (Willink, 2006) is given by the mean of the 2.5 th and 97.5 th percentiles for all events.

For each race, this piecewise exponential model provided successive periods. A period refers to a time slot defined by a group of consecutive performances, following a change of incline. A procedure based on the best adjusted $r^{2}$ was used to split performance series into periods. The algorithm was initiated by the first three performance values. The series was iteratively fitted by adding the next performance value using the equation presented above (Berthelot et al., 2008). For each fit, adjusted $r^{2}$ was obtained, local maxima were identified and thereby defined the years when the slope incline changed, thus defining the beginning of a new period. The minimum period duration was 6 years and the minimum number of performances was three per period.

\section{Mean performance for the 11 races}

The mean speed of the winners of the 11 races was calculated for each year. These values were used to calculate winning riders' mean speed and to provide an index of road cycling performance evolution.

\section{Top-ten analysis}

In addition, we calculated the mean speed of the 11 races' top ten riders each year $(\mathrm{km} \bullet \mathrm{h}-1)$. Standard deviations of the ten best mean speeds were then measured for each race (and for the mean of all races) to calculate the coefficient of variation. The yearly mean coefficient of variation $(c v(t))$ for all races is defined by:

$$
\sigma v(t)=\frac{\sigma_{p}(t)}{p(t)}
$$


where $p(t)$ is the mean value of the top ten performances at year $t$ and $\sigma_{p(t)}$ is the standard deviation of the performance vector; $m c v(t)$ was computed each year from 1892 to 2008, as the mean of the coefficients of variation of the 11 races.

\section{Speed records}

We identified the speed records of each race as the successive best performances ever recorded, and fitted them with the model.

\section{Results}

\section{Mean cycling speed}

Road cycling mean speed progression is shown in Figure 1. This curve shows the yearly speed progression of the 11 races' top ten cyclists and reveals four periods. The mean speed evolution curve of the 11 winners was similar to that of the same races top ten. Winners' speeds ranged from $23.13 \mathrm{~km}$ - $\mathrm{h}^{-1}$ in 1892 (Liège-Bastogne-Liège; Figure 2) to $45.81 \mathrm{~km} \cdot \mathrm{h}^{-1}$ (Milan San Remo 1990). Road cycling mean speed at the beginning of the twentieth century was $26.44 \pm 2.56 \mathrm{~km}^{\bullet} \mathrm{h}^{-1}$, increasing to $41.19 \pm 2.03 \mathrm{~km} \cdot \mathrm{h}^{-1}$ in 2008 . Single-day races had the shortest distances and times; their mean speed records were the highest (Table I).

Period 1 (Figure 1) corresponded to the early years of competitive cycling, before the First World War I. A second period was evident between the world wars. The highest rate of performance increase was seen in this period (from $27.12 \mathrm{~km} \cdot \mathrm{h}^{-1}$ in 1919 to $34.81 \mathrm{~km} \cdot \mathrm{h}^{-1}$ in 1939). A $2.4 \%$ decline was observed during the Second World War, from $34.98 \mathrm{~km} \cdot \mathrm{h}^{-1}$ in 1940 to $34.13 \mathrm{~km} \cdot \mathrm{h}^{-1}$ in 1945 . This was followed by a slow progression (1945-1989) that characterized period 3. In 30 years, from 1960 to 1989 , mean cycling speed was relatively constant at about $37.77 \pm 0.44 \mathrm{~km} \bullet \mathrm{h}^{-1}$. Finally, a late episode of performance improvement (period 4) started after 1993, reaching a peak of $41.23 \mathrm{~km} \cdot \mathrm{h}^{-1}$ in 2003 and a value of $41.19 \mathrm{~km} \cdot \mathrm{h}^{-1}$ in 2008 . The asymptotic value improved by $6.38 \%$ from period 3 to period 4.

\section{Spread of performance}

Mean standard deviation of the top ten riders' performances for each race decreased from $0.60 \pm 0.74$ $\mathrm{km} \cdot \mathrm{h}^{-1}$ in 1909 to $0.11 \pm 0.05 \mathrm{~km} \cdot \mathrm{h}^{-1}$ in 1945 and $0.049 \pm 0.075 \mathrm{~km} \cdot \mathrm{h}^{-1}$ in 2008. The coefficient of variation $(\mathrm{cv}(\mathrm{t}))$ decreased from 0.021 to 0.001 in the same period (Figure 3 ).

\section{Speed records}

The evolution of speed records is shown in Figure 4 for four races: Paris-Roubaix, Tour de France, Fle 'che Wallonne, and Giro d'Italia (mean $\mathrm{R}^{2}=0.94 \pm 0.06$ ). Most recent records varied from 38.93 $\mathrm{km} \cdot \mathrm{h}^{-1}$ (Giro d'Italia 2003) to $45.81 \mathrm{~km} \cdot \mathrm{h}^{-1}$ (Milan San Remo 1990). All current records were set in period 4, except for Paris- Roubaix, which was set in 1964 (due to large modifications of race distance or number and length of cobblestone segments thereafter).

\section{The effect of course profile}

Tour de France characteristics are shown in Figure 5. From 1960 until 1989, when total altitude climbed (A) increased, winners' speed decreased (Figure 5A) - that is, when A increased by $1000 \mathrm{~m}$, the winner's speed decreased by $0.12 \mathrm{~km} \cdot \mathrm{h}-1$ (Figure 5A). Starting in 1990, an inverse relationship was observed: when A increased by $1000 \mathrm{~m}$, the winner' speed increased by $0.10 \mathrm{~km} \cdot \mathrm{h}^{-1}$ (Figure 5B), despite a constant increase in the climbing index (Figure 5C). A linear relationship appeared between distances and speeds (Figure 5D).

\section{Discussion}


This study is the first to analyse the evolution of road cycling performance since its origin in the nineteenth century. Modelling performance with the multiexponential pattern is original and has not been developed by any other group. Previous models (Nevill \& Whyte, 2005; Nevill, Whyte, Holder, \& Peyrebrune, 2007) were used to describe the secular evolution of less than 30 events and did not fit trackand- field jumps and throws, or weightlifting. In addition, previous models did not take into consideration fluctuations relative to external factors such as the impact of world wars, rule changes, and innovations in technology; they fit all performances of an event with a single curve. Our model (Berthelot et al., 2008; Desgorces et al., 2008) has been applied to date to 157 events (including quantifiable Official Olympics events) using a multi-exponential pattern that is sensitive to local fluctuations relative to external factors; it highlights the different progression periods of an event during the century, and each exponential fit of a period is independent from the others for a specific event.

The evolution of road cycling performance (Figure 1) is similar to that reported previously in five quantifiable Olympic disciplines and 10 other major sport events (Berthelot et al., 2008; Desgorces et al., 2008). Four periods were observed in road cycling. The first two were periods of rapid improvement and were each interrupted by a world war. Period 1 was the initiation phase of road cycling before the First World War: large variations in speeds were observed, and only five races were run at that time (Liège-Bastogne-Liège, Paris- Roubaix, Tour de France, Milan-San Remo, and Giro d'Italia, in chronological order). Period 2, between 1919 and 1939, showed the highest rate of performance improvement. During that time the sport matured through the improvement of training techniques, technological innovations including bike composition and gear and transmission development, and economic incentives. After the Second World War, a slight progression was followed by a stabilization phase that characterized period 3. This stabilization was similar to that seen in the post-war evolution of the UCI Hour Cycling record (Desgorces et al., 2008). All progression curves of road cycling and previously studied sports disciplines (Berthelot et al., 2008; Desgorces et al., 2008) follow the same piecewise exponential pattern.

In road cycling, however, a new progression phase started after 1993. It was observed in 10 of the 11 races studied and occurred after 30 years of stagnation, generating a new asymptote (period 4). Performance improved by $6.38 \%$ (Figure 1) as the asymptotic speed increased from $37.85 \mathrm{~km} \cdot \mathrm{h}^{-1}$ in period $3(1960-1992)$ to $40.26 \mathrm{~km} \cdot \mathrm{h}^{-1}$ in period 4 (1993-2008).

Speed gaps between the top ten riders also diminished and performances became more similar. The coefficient of variation between the top ten cyclists' mean speed (Figure 3) rapidly decreased from 1909 until 1950 (0.021 to 0.003), and then varied in a small range (0.001). These values are much smaller in cycling than in swimming or track and field (Berthelot et al., 2010). In road cycling, the whole group sets the pace; when the winner's speed record is improved, the group record improves in parallel, and vice versa.

Cycling performance is determined by the interrelationship of physiological, biomechanical, and technological factors. Technological improvement contributed to equipment development, especially bicycles. Bicycles weighed approximately $40 \mathrm{~kg}$ in 1869 and then decreased to $18 \mathrm{~kg}$ in the $1930 \mathrm{~s}$ (Industrie du vélo, undated). In 1934, Duralumin substituted steel and reduced the weight to $12 \mathrm{~kg}$ (Industrie du vélo, undated). Today's bikes are made of titanium, aluminium or carbon composites with higher rigidity (first used in 1986 in the Tour de France), with a weight of 7-8 kg - that is, less than $10 \%$ of the total "system" weight (bike + body weight) (Jeukendrup \& Martin, 2001). Other technical features may have also influenced the observed speed progression. For example, aerodynamic handlebars, first used in the 1989 Tour de France (Faria et al., 2005); derailleurs, introduced in 1937 in the Tour de France; and the recent introduction of twoway radios, allowing communication with coaches and team-mates. Technology (bicycle weight reduction and aerodynamic optimization) largely influenced the IHPVA (International Human Powered Vehicle Association) Hour cycling record $(90.597 \mathrm{~km})$ from 1979, and almost doubled physiological performance (the UCI hour record is currently $49.70 \mathrm{~km}$ when using equipment similar to Eddy Merckx's bike) (Desgorces et al., 2008). While a highly optimized technical configuration is proven effective in increasing speed in track cycling races, held in standardized conditions, it remains effective to a lesser extent in road cycling (Faria et al., 2005). The only circumstances under which a highly optimized bike configuration may be useful in road cycling are individual and team time-trials, which represent a very small proportion of the overall race ( $83 \mathrm{~km}$ only in the 2008 Tour de France, which was $3560 \mathrm{~km}$ long). 
While aerodynamic parameters such as body position or bicycle frame may influence performance, tactics adopted or the position of teammates may also be determining factors (Jeukendrup \& Martin, 2001). The impact of technology on cycling performance can be compared with its impact on swimming (Berthelot et al., 2010). Indeed, recent progression phases began in 1999 when swimsuits were allowed by the International Swimming Federation (FINA), and in 2008 after further refinement (Neptune, McGowan, \& Fiandt, 2009).

Many other factors are involved in road cycling performance, including adequate nutrition, which is essential in the preparation of high-level competitors. Media coverage may also play a role, although this has been prevalent since the earliest bicycle races (Musée National du Sport, 2007).

Although prohibited substances have probably been used since the end of the Second World War, some major pharmacological innovations appeared at the beginning of period 4 (Diamanti-Kandaris et al., 2005; Gaudard, Varlet-Marie, Bressolle, \& Audran, 2003; Juhn, 2003; Lucia, Earnest, \& Arribas, 2003). However, no previous publications have included this factor when modelling road cycling performance. The erythropoietin (EPO) gene was identified and cloned in 1985, and recombinant human EPO (rHuEPO) was approved by the US Food and Drug Administration in 1989 (Gaudart et al., 2003). The International Olympic Committee (IOC) prohibited its use in sports in 1990 (DiamantiKandaris et al., 2005), but since then rHuEPO has been used by 3-7\% of elite endurance-sport athletes to increase maximal oxygen consumption and endurance (Diamanti- Kandaris et al., 2005; Gaudart et al., 2003; Juhn, 2003). Major and recurrent judiciary procedures were to follow throughout period 4 (Berry, 2008; Lucia et al., 2003; Miquet \& Blanchet, 2000; Noakes, 2004; Robinson et al., 2000). Some studies quantified the effect of EPO on performance in volunteering athletes by measuring maximal oxygen uptake ( $\mathrm{V} \mathrm{O} 2 \mathrm{max}$ ). These studies showed a $6.3-6.9 \%$ increase in $\mathrm{V}$ O2max (Ashenden et al., 2001; Birkeland et al., 2000; Parisotto et al., 2000), with a significant elevation that remained 4 weeks after the cessation of drug administration (Russell, Gore, Ashenden, Parisotto, \& Hahn, 2002). These findings confirm that $\mathrm{rHuEPO}$ doping provides a significant physiological advantage consistent with the increase in road cycling performance shown in the present study. Cycling speed and VO2max are correlated in road cycling (McCole, Claney, Conte, Anderson, \& Hagberg, 1990), as in all other aerobic sports (track and field, middle-and long-distance running, cross-country skiing, rowing; Seiler, 2006). In a previous study, McCole et al. (1990) showed that an increase in speed from 37.5 to $40 \mathrm{~km} \cdot \mathrm{h}^{-1}$ may be related to a $7.5 \%$ increase in VO2max. The expected effect on VO2max has been the major incentive to use EPO in aerobic sports since its discovery. Newly synthesized molecules, undetectable in urine-based doping controls, such as EPO CERA (detected in targeted controls only in 2008), may still be in use by some athletes (Schöffel, Börger, Quarcoo, Scutaru, \& Groneberg, 2008). The sudden increase in performance observed during period 4 in this study and the availability of rHuEPO may be coincidental, and unless the direct effect of rHuEPO's on elite road cycling performance is measured, it is impossible to prove that its use alone is responsible for the $6.38 \%$ improvement in period 4 .

The relationship between total altitude climbed and the winner's mean speed in the Tour de France raises another physiological issue. Between 1960 and 1989, the relationship is coherent (Figure 5A). However, in the 1990s, when the climbing index increased, the winner's speed paradoxically increased too (Figure 5B). In the last 20 years, increased mountain biking during the Tour resulted in a faster Yellow Jersey ending the race. During period 4, total distance (D) in the Tour de France increased from $3285 \mathrm{~km}$ to $3944 \mathrm{~km}$ (1989-1997) and total altitude climbed (A) increased from 24,308 $\mathrm{m}$ to $41,057 \mathrm{~m}$. In theory, both of these changes should make the race more difficult. The expected result would have been a decrease in mean speed $[11.3 \%$ speed reduction due to the increased race distance (Figure 5D), and 6.5\% speed reduction due to the increase in A (Figure 5A)]. In fact the change observed was a $4.5 \%$ improvement (from $37.48 \mathrm{~km} \cdot \mathrm{h}^{-1}$ in 1989 to $39.24 \mathrm{~km} \cdot \mathrm{h}^{-1}$ in 1997), contributing to the $6.38 \%$ improvement of global road cycling progression in period 4 (Figure 1).

\section{Conclusion}

We studied road cycling performance and demonstrated that like other indoor and outdoor sports, its evolution follows a piecewise exponential progression. However, after 30 years of stagnation, a blunt progression phase was observed after 1993, with a $6.38 \%$ increase in mean cycling performance. 
Although further research is required to validate the direct causes and consequences of our findings, performance modelling has important implications for the role of extra-physiological parameters.

\section{Acknowledgments}

We thank the Centre National de De'veloppement du Sport and the Ministry of Health, Youth, and Sport for financial assistance. We thank INSEP teams for their full support. We thank Mr. Dominique Magnier, President of "Association Memoire du Cyclisme", for giving us full access to his database. We thank Mrs. Karine Schaal for carefully reviewing the manuscript. 


\section{References}

Ashenden, M. J., Hahn, A. G., Martin, D. T., Logan, P., Parisotto, R., \& Gore, C. J. (2001). A comparison of the physiological response to simulated altitude exposure and r-HuEpo administration. Journal of Sports Sciences, 19, 831-837.

Association Mémoire du Cyclisme website. (undated). Road cycling races results. Retrieved from: http://www.memoire-ducyclisme.net/.

Basset, D. R., Kyle, C. R., Passfield, L., Broker, J. P., \& Burke, E. R. (1999). Comparing cycling world hour records, 1967-1996: Modelling with empirical data. Medicine and Science in Sports and Exercise, $31,1665-1676$.

Berry, D. A. (2008). The science of doping. Nature, 454 (7), 693.

Berthelot, G., Tafflet, M., El Helou, N., Len, S., Escolano, S., Guillaume, M. et al. (2010). Athlete atypicity on the edge of human achievement: Performances stagnate after the last peak, in 1988. PLoS ONE, 5 (1), e8800. DOI: 10.1371/journal.pone.0008800.

Berthelot, G., Thibault, V., Tafflet, M., Escolano, S., El Helou, N., Jouven, X. et al. (2008). The Citius End: World records progression announces the completion of a brief ultraphysiological quest. PLoS ONE, 3 (2), e1552. DOI: 10.1371/journal.pone.0001552.

Birkeland, K. I., Stay-Gundersen, J., Hemmersbach, P., Hallen, J., Haug, E., \& Bahr, R. (2000). Effect of rhEPO administration on serum levels of sTfR and cycling performance. Medicine and Science in Sports and Exercise, 32, 1238-1242.

Desgorces, F. D., Berthelot, G., El Helou, N., Thibault, V., Guillaume, M., Tafflet, M. et al. (2008). From Oxford to Hawaii ecophysiological barriers limit human progression in ten sport monuments. PLoS ONE, 3 (11), e3653. DOI: 10.1371/journal.pone.0003653.

Diamanti-Kandaris, E., Konstantinopoulos, P. A., Papailiou, J., Kandarakis, S. A., Andreopoulos, A., \& Sykiotis, G. P. (2005). Erythropoietin abuse and erythropoietin gene doping: Detection strategies in the genomic era. Sports Medicine, 35, 831-840.

Faria, E. W., Parker, D. L., \& Faria, I. E. (2005). The science of cycling: Factors affecting performance - Part 2. Sports Medicine, 35, 313-337.

Gaudard, A., Varlet-Marie, E., Bressolle, F., \& Audran, M. (2003). Drugs for increasing oxygen transport and their potential use in doping: A review. Sports Medicine, 33, 187-212. 
Gonza'lez-Haro, C., Galilea Ballarini, P. A., Soria, M., Drobnic, F., \& Escanero, J. F. (2007). Comparison of nine theoretical models for estimating the mechanical power output in cycling. British Journal of Sports Medicine, 41, 506-509. IGN-Institut Géographique National web site. Mountain summits altitudes. Retrieved from: http://www.ign.fr.

Industrie du vélo web site (undated). Homepage. Retrieved from: http://www.toovelo.com/content/view/5/11/\#retour.

Jeukendrup, A. E., Craig, N. P., \& Hawley, J. A. (2000). The bioenergetics of world class cycling. Journal of Science and Medicine in Sport, 3, 414-433.

Jeukendrup, A. E., \& Martin, J. (2001). Improving cycling performances, how should we spend our time and money. Sports Medicine, 31, 559-569.

Juhn, M. S. (2003). Popular sports supplements and ergogenic aids. Sports Medicine, 33, 921-939.

La Gazetta Dello Sport web site (undated). Giro official results. Retrieved from: http://www.gazzetta.it/Speciali/Giroditalia/.

Lucia, A., Earnest, C., \& Arribas, C. (2003). The Tour de France: A physiological review. Scandinavian Journal of Medicine and Science in Sports, 13, 275-283.

Lucia, A., Hoyos, J., \& Chicharro, J. L. (2001). Physiology of professional road cycling. Sports Medicine, 31, 325-337.

McCole, S., Claney, K., Conte, J. C., Anderson, R., \& Hagberg, J. M. (1990). Energy expenditure during bicycling. Journal of Applied Physiology, 68, 748-753.

Miquet, P., \& Blanchet, B. (2000). Le roman de l'EPO. L'Express [updated 3 December 2003; published 29 June 2000].

Retrieved from: http://www.lexpress.fr/actualite/sciences/sante/le-roman-de-1-epo_494198.html.

Musée National du Sport (2007). Histoire du Sport en France Du Second Empire au Re'gime de Vichy (pp. 330-338). Paris: Vuibert.

Neptune, R. R., McGowan, C. P., \& Fiandt, J. M. (2009). The influence of muscle physiology and advanced technology on sports performance. Annual Review of Biomedical Engineering, 11, 81-107. 
Nevill, A. M., \& Whyte, G. P. (2005). Are there limits to running world records? Medicine and Science in Sports and Exercise, 37, 1785-1788.

Nevill, A. M., Whyte, G. P., Holder, R. L., \& Peyrebrune, M. (2007). Are there limits to swimming world records? International Journal of Sports Medicine, 28, 1-6. Noakes, T. (2004). Tainted glory doping and athletic performance. New England Journal of Medicine, 351, 847-849.

Olds, T. S., Norton, K. I., \& Craig, N. P. (1993). Mathematical model of cycling performance. Journal of Applied Physiology, 75, 730-737.

Olds, T. S., Norton, K. I., Lowe, E. L., Olive, S., Reay, F., \& Ly, S. (1995). Modeling road-cycling performance. Journal of Applied Physiology, 78, 1596-1611.

Padilla, S., Mujika, I., Orbananos, J., \& Angulo, F. (2000). Exercise intensity during competition time trials in professional road cycling. Medicine and Science in Sports and Exercise, 32, 850-856.

Parisotto, R., Gore, C. J., Emslie, K. R., Ashenden, M. J., Brugnara, C., Howe, C. et al. (2000). A novel method utilizing markers of altered erythropoiesis for the detection of recombinant human erythropoietin abuse in athletes. Haematologica, 85, 564-572.

Robinson, N., Schweizer, C., Cardis, C., Saugy, M., Kamber, M., Schattenberg, L. et al. (2000). Haematological and biochemical parameters from all professional cyclists during the Tour de Suisse 1999. Schweizerische Zeitschrift fü r Sportmedizin und Sporttraumatologie, 48 (3), 104-110.

Russell, G., Gore, C. J., Ashenden, M. J., Parisotto, R., \& Hahn, A. G. (2002). Effects of prolonged low doses of recombinant human erythropoietin during submaximal and maximal exercise. European Journal of Applied Physiology, 86, 442-449.

Schöffel, N., Börger, J. A., Quarcoo, D., Scutaru, C., \& Groneberg, D. A. (2008). Erythropoietin - state of science. Sportverletz Sportschaden, 22, 201-206.

Seiler, S. (2006). One hundred and fifty years of rowing faster. Sportscience, 10, 12-45.

Tour de France official web site (undated). Tour de France official data. Retrieved from: http://www.letour.fr.

Web Oficial de la Vuelta a España (undated). Vuelta official results. Retrieved from: http://www.lavuelta.com. 
Willink, R. (2006). On using the Monte Carlo method to calculate uncertainty intervals. Metrologia, $43,39-42$. 


\section{Figures}

Figure 1. Mean cycling speed progression curve of the top ten riders in 11 European professional bicycle races. Four periods are observed; the first three included the two World Wars (from P1 to P3). A fourth period (P4) appears after 1993.

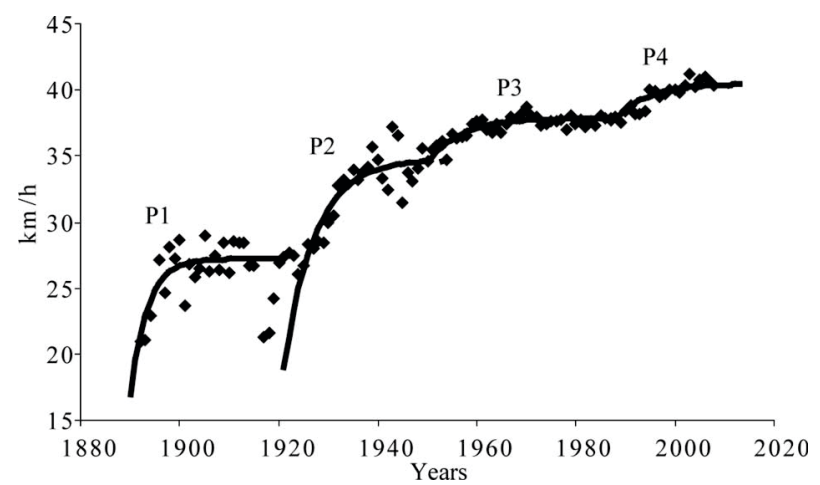

Figure 2. Liège-Bastogne-Liège winners' speed progression. A new period appears after 1990 with a speed progression of $5.07 \%$ compared with the previous asymptote (mean $\mathrm{R}^{2}=0.54 \pm 0.1$ ).

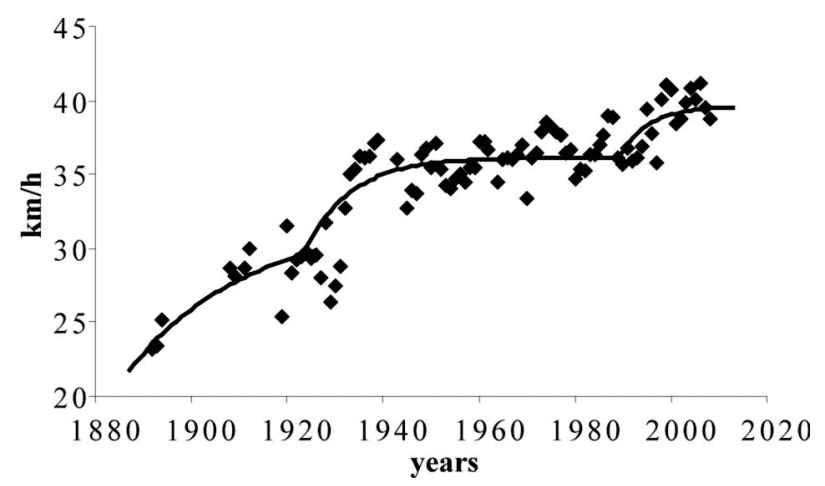

Figure 3. Mean coefficient of variation progression curve for the 10 best riders of each race $\left(\mathrm{R}^{2}=\right.$ $0.73)$.

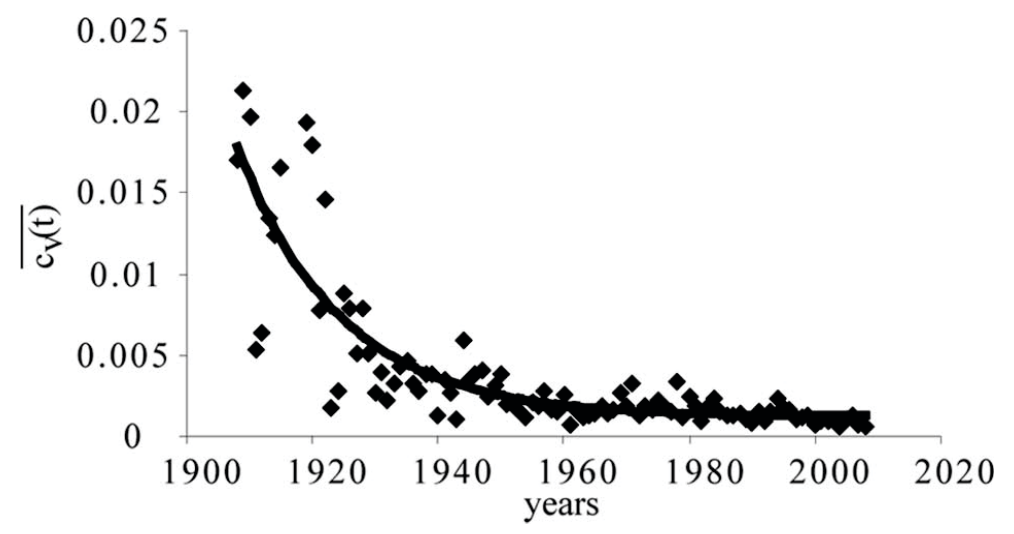


Figure 4. Model fitting on the speed records of four professional bicycle races. (A) Paris-Roubaix (mean $\mathrm{r}^{2}=0.95$ ); (B) Tour de France (mean $\mathrm{r}^{2}=0.98$ ); (C) Vuelta (mean $\mathrm{r}^{2}=0.93$ ); (D) Giro (mean $\mathrm{r}^{2}$ $=0.86$ ). The curve for Paris-Roubaix curve has been reset in 1964 with a new course (relative increase in cobblestone segments due to a reduction in the normal road portion).
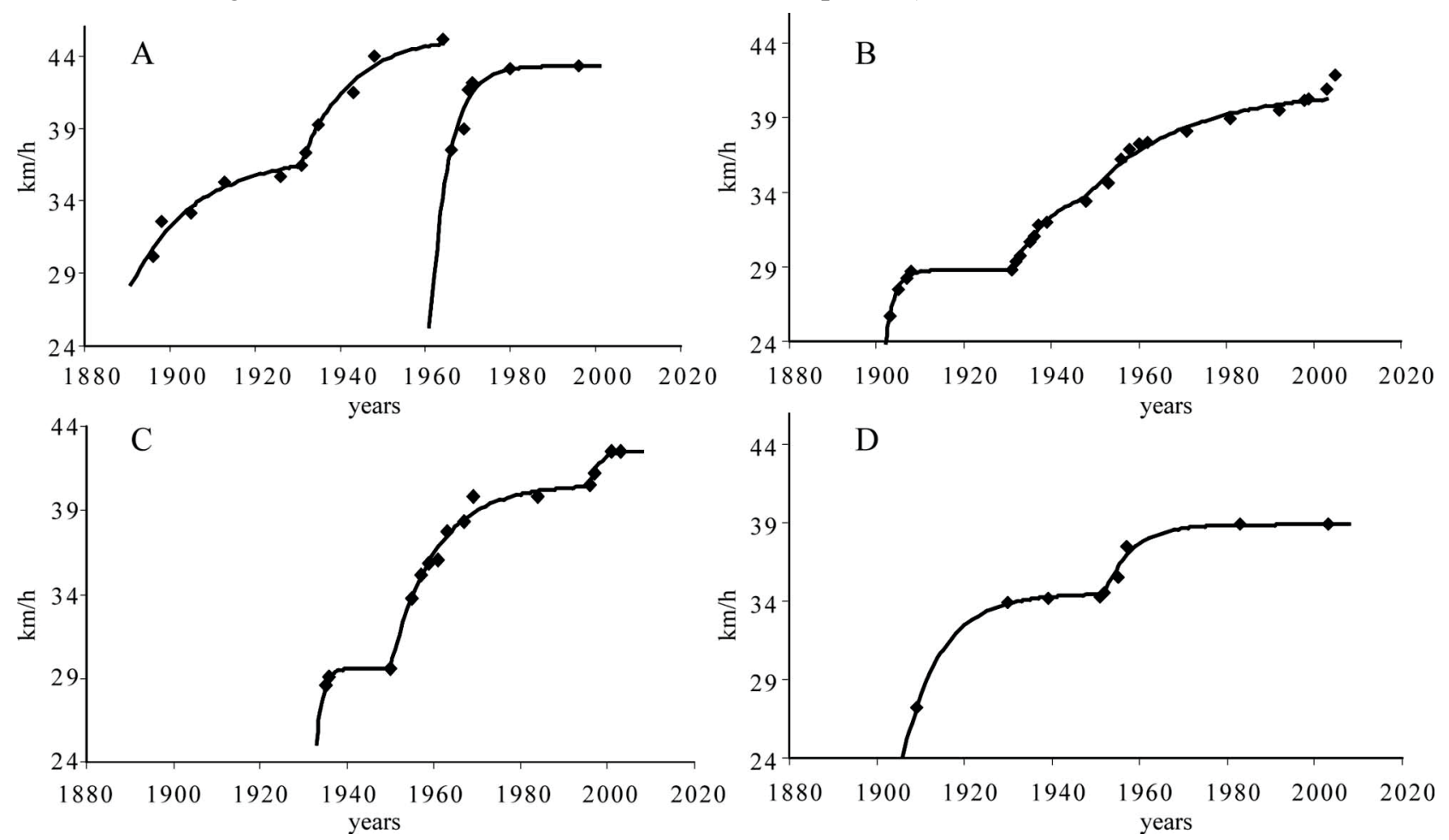
Figure 5. Relationship between total altitude climbed and winners' mean speeds for: (A) Tour de France (1960-1989; $y=-0.0001 x+40,484$, (B) Tour de France $(1990-2008 ; y=1 E-04 x+36,344)$. (C) Climbing index (mean slope) for the Tour de France $\left(y=0.098 x-185 ; r^{2}=0.54\right)$.

(D) Relationship between total distance and winners' mean speed in the Tour de France between 1947 and $2008\left(\mathrm{y}=70.0046 \mathrm{x}+55.6 ; \mathrm{r}^{2}=0.67\right)$.
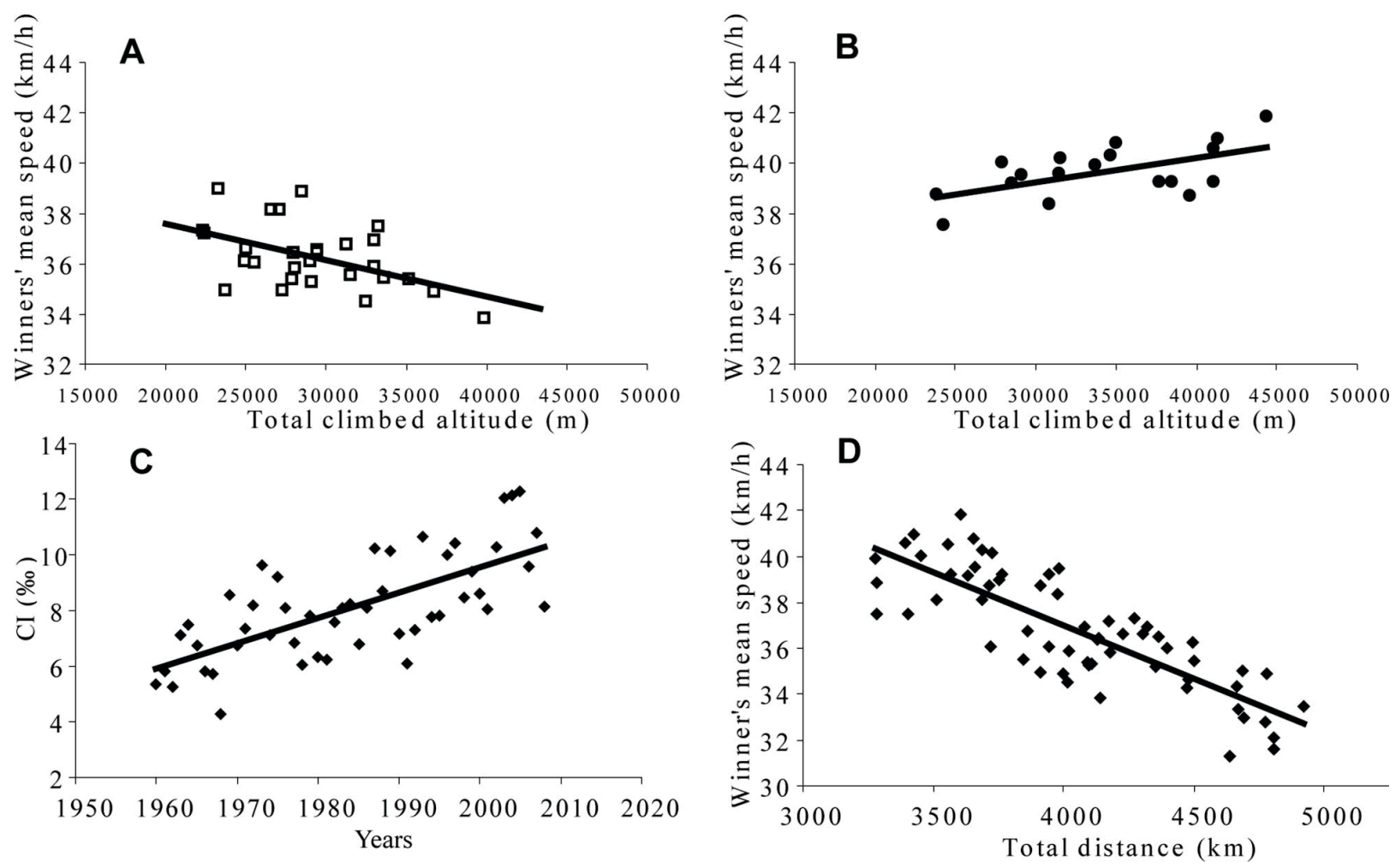

Table I. Race categories.

\begin{tabular}{lccc}
\hline Category & Date first raced (year) & Beginning speed $\left(\mathrm{km} \cdot \mathrm{h}^{-1}\right)$ & Last speed record $\left(\mathrm{km} \cdot \mathrm{h}^{-1}\right)$ \\
\hline Single-day races & $1907.8 \pm 19.8$ & $28.17 \pm 4.51$ & $44.05 \pm 2.03$ \\
Stage races Tours & $1946.0 \pm 9.3$ & $35.99 \pm 2.80$ & $43.16 \pm 2.54$ \\
All 11 races & $1915.7 \pm 17.0$ & $27.16 \pm 1.44$ & $41.53 \pm 1.14$ \\
& $1923.8 \pm 22.8$ & $30.74 \pm 5.14$ & $42.88 \pm 2.02$
\end{tabular}

Note: Single-day races have the shortest distances; they were the first to start (in $1907 \pm$ 19.8 years) and are the fastest ones (record: $44.05 \pm 2.03 \mathrm{~km} \cdot \mathrm{h}^{-1}$ ). Stage races started after the Second World War (1946 \pm 9.3 years); they have the highest beginning speed $\left(35.99 \pm 2.80 \mathrm{~km} \cdot \mathrm{h}^{-1}\right)$. The Tours are the longest races, and consequently have lower speeds (record: $41.53 \pm 1.14 \mathrm{~km} \cdot \mathrm{h}^{-1}$ ). 